\title{
Unlocking Climate Finance Potential for Climate Adaptation: Case of Climate Smart Agricultural Financing in Sub Saharan Africa
}

\author{
Edward M. Mungai, S. Wagura Ndiritu, and Izael da Silva
}

\section{Contents}

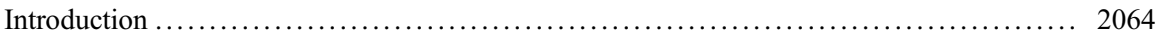

The Concept of Climate-Smart Agriculture .................................. 2067

The Potential for Climate-Smart Agriculture in Sub-Saharan Africa ................ 2067

Climate-Smart Agriculture Opportunities and Impeding Challenges in Sub-Saharan

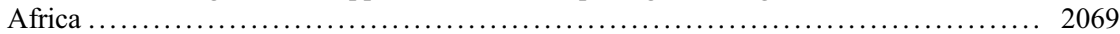

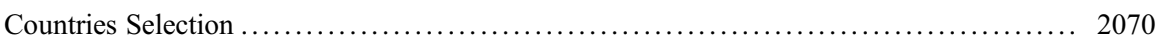

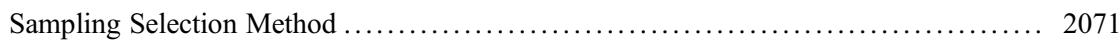

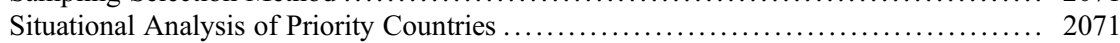

Estimating Climate Investment Potential ..................................... 2071

CSA Financial Potential and Barriers Associated with CSA Financing ................ 2073

Financing Potential for Climate-Smart Agriculture in Sub-Saharan Africa ............ 2073

Barriers Hindering the Private Sector from Investing in CSA in Africa ............. 2075

Conclusion ............................................................... 2079

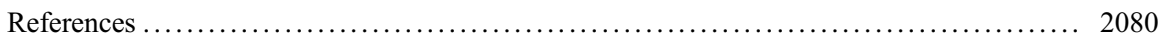

This chapter was previously published non-open access with exclusive rights reserved by the Publisher. It has been changed retrospectively to open access under a CC BY 4.0 license and the copyright holder is "The Author(s)". For further details, please see the license information at the end of the chapter.

E. M. Mungai · S. W. Ndiritu

Strathmore University Business School, Nairobi, Kenya

e-mail: emungai@kenyacic.org; sndiritu@strathmore.edu

I. da Silva $(\bowtie)$

Strathmore University, Nairobi, Kenya

e-mail: idasilva@strathmore.edu 


\section{Abstract}

Climate change has emerged as one of the greatest challenges faced by the world today. Adverse impacts of climate change are visible across sectors like agriculture and other natural resources due to increasing average temperature and changing weather patterns. Africa constitutes around 13\% of the global population but contributes the least (around 2\%) to greenhouse gas (GHG) emissions globally. Concerning the global climate vulnerability index, Africa is most impacted (around $21 \%$ ) by climate change and its' population is most vulnerable to climate sensitivity and fragility of the continent's natural environment and increasingly erratic weather patterns, low adoption of climate-resilient technologies, and high dependence on environment-based livelihoods. Hence, Africa needs to adopt low carbon and climate-resilient development to address climate-related issues and to have sustainable development. In line with the low carbon/climate-resilient development agenda, 53 countries (except Libya) have submitted Nationally Determined Contribution (NDC) and have set ambitious targets under NDC and Sustainable Development Goals. A quick analysis of the NDCs and various studies indicates the enormity of the financing needs. According to Climate Invetsment Funds (CFI), Sub-Saharan Africa will require an estimated USD222 billion for climate resilience investments to reach its NDCs. One of the critical stakeholders to play a key role in meeting the financing needs of climate-smart agriculture (CSA) related targets is the private sector. There is around $98 \%$ gap in financing for CSA. Even though substantial climate finance potential exists in selected countries for the private sector, there are certain challenges and barriers like financial, policy, lack of awareness, and low provision for climate funding in the national budget.

\section{Keywords}

Climate-smart agriculture $\cdot$ Unlocking climate finance $\cdot$ Sub-Saharan Africa Climate adaptation · Private sector

\section{Introduction}

An additional 2.4 billion people - representing a one-third increase in the global population - will occur between 2013 and 2050 (FAO 2013). Further, the Food and Agriculture Organization (FAO) approximates the additional population will translate into a $60 \%$ increase in demand for agricultural production. Undoubtedly, agriculture is well-positioned to be a reliable basis for economic growth and poverty reduction. Conversely, the ongoing global environmental concern of climate change has adverse impacts on agriculture that is also a contributing factor to the drastically changing weather and climatic patterns. Consequently, for agriculture to satisfactorily feed the growing population, the current agriculture practices need to spiral into more adaptive hence sustainable practices. A breakthrough hinged on climate-smart 
agriculture (CSA) approach that encompasses three perspectives: increasing productivity in a sustainable manner, enhancing adaptation/resilience, and mitigating the emission of greenhouse gases (GHGs) as emerged as a way to realize food security and achieve the developmental goals. Notably, $56 \%$ of Africa's population will reside in urban areas by 2025 and half of the projected population growth will be in Sub-Saharan Africa (UNDESA 2019 and 2014). This entails that agriculture, specifically in Africa, has to undergo a major transformation to fulfill the intertwined challenges of achieving food security, reducing poverty, and responding to climate change without depletion of the natural resource base. Despite the common consensus on the potential for climate-smart agriculture in Africa, there is a conspicuous paucity in wholesome quantifiable empirical evidence. To fill this gap, this chapter looks into the potential for climate-smart agriculture in 14 select countries in SubSaharan Africa (SSA) representing East, West, Central, and Southern Africa.

World Bank (2015) estimates that about $48 \%$ (approximately 450 million people) of Africa's population live in extreme poverty, i.e., less than US \$1.25 in a day. Also, $63 \%$ of Africa's population lives in rural areas, wholly dependent on agriculture as a source of living (World Bank 2015). More than $60 \%$ of the African population works in the agricultural sector that accounts for about $25-34 \%$ of the continent's gross domestic production (GDP). Conceivably, agriculture looms large in the African economy. Unfortunately, a collective report by FAO, IFAD, and WFP (2014) revealed that agricultural production is low leading to high food insecurity. A reason attributed to sluggish income growth, high poverty rates, and dilapidated infrastructure in the rural areas that impair market access. A situation further exacerbated by weak policies, civil unrest, periodical disease outbreaks, overlapping rules, poor coordination, and inept collaboration among institutions within the climate-smart agriculture realm. One in four people remains malnourished in Africa with a high prevalence of stunted and underweight children due to poor dietary quality and diversity, mostly among the poor. Increasing agriculture's adaptive capacity will be necessary to prevent a slide back into poverty and hunger.

Growth in agriculture is the most viable and equitable strategy to spur economic growth in Africa by reducing poverty and enhancing food security in Africa. However, it has to overcome the climate change-related challenges. For instance, Barkhordarian et al. (2012), Radhouane (2013), and IPCC (2014) postulated that the annual rainfall in Sub-Saharan Africa will possibly decrease by about $4-47 \%$ resulting in droughts and increased salinity. It resonates with Intergovernmental Panel for Climate Change observations that crop and fodder growing periods in both western and southern Africa will likely shorten by an average of $20 \%$ by the year 2050. Resultantly, there will be a $40 \%$ decline in cereal yield and an additional reduction in cereal biomass for livestock (Lobell et al. 2011). According to Hoerling et al. (2006) western, central, and southern Africa will record a decline in the mean annual rainfall of $4 \%, 5 \%$, and $5 \%$, respectively. In the rest of Africa, drought conditions will not only be more frequent and intense but also more long-lasting leading to an increase in the arid and semiarid area approximately to about $5-8 \%$ by 2080 (Elrafy 2009). As a factor attributed to the sensitivity of the current farming systems to drought, the cumulative crop yield decline across the continent is 
forecasted at $50 \%$ by 2020 . Thornton et al. (2008) contend that the net revenues from crops may likely fall by about $90 \%$ by 2100 . Further, both agropastoral, pastoral, and mixed-crop livestock systems will potentially be affected by a constraint of animal feed and water in addition to advancing pest severity and disease distribution (Thornton et al. 2008). Against such a grim picture, there lies an excellent opportunity with CSA for transformation by collating agriculture, economic growth, and climate change under the umbrella of sustainable development. Four agroecological zones in SSA serves as case studies for underlying CSA investment potential.

To facilitate CSA adoption in developing countries, respective governments' have claimed their right to public grants with lesser regard to private financing (Pauw 2014). The latter predisposition of the developing countries is in line with the United Nations Framework Convention on Climate change (UFCC) principle of "the polluter pays." The approach implies that developed countries should play a greater role in providing climate adaptation finance for being major contributors of climate change. Bindingly, developed countries pledged US $\$ 100$ billion every year from 2020 onwards (UFCC 2011). A target that Pauw et al. (2015) doubts if it will be met, actually UNEP FI (2009) postulates that public funding cannot sufficiently finance climate change adaptation costs. Pauw (2014) proposes that the private sector can supplement but not substitute public investment in climate finance. Observations by UFCC (2007) approximated the global private sector investment and financial flows at $86 \%$. Further, SER (2011) cite that $90 \%$ of the population in emerging economies depends on the private sector as a source of income. Pauw and Pegels (2013) argues that the private sector can play a potentially significant role in adaptation engagement. As a result of the private sector potential, it was included as one of the finance sources. However, as put forward by Surminski (2013), the evidence base - reasonable activity, predictable returns and acceptable risk for private sector investment - is limited (Christiansen et al. 2012).

This chapter will contribute to the extant literature in twofolds. First is a pioneering academic exploration into quantifying the investment potential and the funding gap in climate-smart agriculture in Africa. This is unlike recent work of Tran et al. (2019) that focused on determinants for the adoption of CSA technologies in developing countries and Pauw and Pegels (2013) with a reflection on the role of the private sector in developing countries. This chapter also digresses from a study by Zougmoré et al. (2018) and Nciizah and Wakindiki (2015) that looked into the prospects and the achievements of CSA in Africa. Secondly, unlike past generalizations on the areas that need climate financing, this chapter will identify the financial, regulatory, and policy barriers hindering private sector investment into CSA projects in Sub-Saharan Africa. In general, this work will add to the ongoing research on the conceptual clarity of private sector engagement in climate adaptation in developing countries (Pauw and Pegels 2013; Pauw 2014).

Based on the selected sample, this work found out that the highest climate-smart agriculture finance potential (in USD billion) lay with Ethiopia at USD 26 billion, distantly followed by Nigeria at USD 17 billion, and further down is Kenya at USD 9 billion which is almost the same case for Madagascar at USD 8 billion. Interestingly, CSA was termed as more investor-friendly, receiving a cumulative investment of 
USD 79 billion in the 14 countries. Notwithstanding the CSA potential, the sector faces several challenges including inadequate financing, weak policies, and knowledge gaps within the key institutions. Nonetheless, there is a $98 \%$ untapped climatesmart agriculture investment potential that the private sector can exploit through climate financing.

The remainder of this chapter proceeds as follows. The second section will provide an elaborate literature review while the following section will look into the methodology that was used to come up with the conclusions and recommendation. Finally, the chapter will conclude by presenting the conclusion and recommendations.

\section{The Concept of Climate-Smart Agriculture}

The approach to developing the technical capacity, accommodative policies and create an enabling environment for investment towards sustainable agriculture in the face of climate change was put forward by FAO (2013). CSA simultaneously addresses the global concerns of food security, ecosystem management, and climate change, therefore incorporating the three dimensions of sustainable development: economic, social, and environmental conditions. Nciizah and Wakindiki (2015) identifies three pillars of CSA as: (1) sustainably increasing agricultural productivity from crops, livestock, and fisheries without detrimental effects to the ecosystem, (2) reducing short-term farming shocks while enhancing their resilience by increasing farmers adaptability to long-term stresses, and (3) mitigating (GHG) emissions by either removing or reducing possible pollution instances. At the grassroots, CSA is intended to bolden the livelihoods through food security mostly among the small-scale farmers. This is by improving the management of natural resources and shifting to suitable technological approaches for the production, processing, and marketing farm produce. Relatedly, at the national level, CSA is tailored to prompt mainstreaming of policy, technical, and financial mechanisms that facilitate a base for operationalization of climate change adaptation within the agriculture sector. There is a vast array of CSA technologies that can be used singly or in combination in response to various environmental conditions (Teklewold et al. 2017). But mainly, the adoption of CSA technologies among farmers differs based on cultures, preferences, awareness, socioeconomic backgrounds, and resource availability (Maguza-Tembo et al. 2017). However, successful CSA requires an appropriate match between agricultural production technologies with social, economic, and environmental conditions.

\section{The Potential for Climate-Smart Agriculture in Sub-Saharan Africa}

In West Africa, there is a high and fast-growing population and increasing agricultural production intensification to meet the growing food demand is very limited. Buah et al. (2017), Jalloh et al. (2012), and Sanou et al. (2016) postulate that to enhance food security in West Africa there will be a need to have animals that have resilient genetic potential, drought-resistant crop varieties that are also hardly 
affected by insects and diseases. Besides, the management of soil carbon and fertility techniques will be handy for the region. Jalloh et al. (2012) also note that increasing capabilities among the smallholders and large-scale irrigated farms are likely to open up new opportunities for CSA through approaches such as crop-livestock interactions. CSA opportunities in Central Africa lie from an increasing but also a foodinsecure population. In this case, sustainably increasing agricultural productivity will not only enhance food security but will also prevent deforestation. CSA aims at limiting the expansion of cultivated land into forests by seeking alternatives in better agricultural techniques that are productive hence restoring lost ecosystems.

Torquebiau (2015) contends that to enhance food security in East Africa, CSA practices need to put more emphasis on increasing livestock productivity, soil conservation, and management of water and natural resources at both landscape and small-scale levels, adaptive intensification of the cropping systems. Further, Partey et al. (2016) and Zougmoré et al. (2015) observed that CSA innovations in East Africa should expound into agroforestry, development of stress-tolerant crops and livestock, crop-livestock diversification, as well as combining conservation agriculture with integrated soil fertility management. For instance, research by Wambugu et al. (2011) in Western Kenya found out that short-term agroforestry fallows being used in some parts of Western Kenya increased the annual net income of farmers to between US $\$ 62$ and 122. Such interventions need to be adopted across Africa although with regional-suited species.

According to Mapfumo et al. (2015), South Africa rainfall is expected to decrease and incidences of drought to increase just like other parts of Africa. Similarly, like East Africa, South Africa has to increase its agricultural productivity through intensification. The most crucial CSA approaches in South Africa will be integrated soil, water, nutrient, and organic manure management (Mapfumo et al. 2015). Additionally, soil carbon, salinity, and organic matter regulation will be critical gains for CSA in empowering the smallholder communities to overcome the food shortages and nutrient scarcity. Mbow et al. (2014) also advocated for the use of legume cereal rotational systems in South Africa that should be combined with inorganic fertilizers.

Majority of the Intended Nationally Determined Contributions (INDCs) have referenced agriculture as an adaptation priority, despite that in most cases, there are no cost estimates and adequate financial mechanisms (World Bank 2016). Of critical value in realizing the adaptation objectives is increasing the working and investment capital in climate-smart agriculture. In 2014, the total climate finance mobilized globally was US $\$ 391$, and despite agriculture's vulnerability to climate change, only US \$6-8 billion was committed to livestock, fisheries, and crops. Ironically, the total financing demand for smallholder farmers in Latin America, Asia, and Sub-Saharan Africa was estimated at $\$ 210$ billion. Consequently, agriculture in developing countries has a challenge of access to sufficient and adequate finance due to high and perceived risks, low margins for financiers, and profitability. As a result, financiers limit their exposure, raise the interest rates, tighten the lending requirements, shorten lending durations, and others opt for other economic sectors with stable returns (World Bank 2016). Among the factors contributing to 
the funding gap are imbalanced risk-reward profiles, limited capacity to identify financial needs for adaptation, and insufficient evidence bases to identify suitable climate-smart practices and potential. Therefore, there is need to hypothesis that there is a substantial climate-smart agriculture investment potential in African countries.

\section{Climate-Smart Agriculture Opportunities and Impeding Challenges in Sub-Saharan Africa}

In June 2014, leaders from African Union member states endorsed the adoption of CSA in the New Partnership for Africa's Development (NEPAD). Further, the summit crafted the African Climate-Smart Agriculture Alliance whose aim was to partner with regional economic communities and nongovernmental organizations in enhancing NEPAD planning and coordination to impact on 25 million farm households by the year 2025. Progressively, ECOWAS (2015) and Zougmoré et al. (2015) note that Economic Community of West African States (ECOWAS) initiated the West Africa CSA Alliance to imbed climate-smart agriculture within the programs of ECOWAS Agricultural Policy (ECOWAP)/Comprehensive Africa Agricultural Development Program (CAADP). Respective heads of states that are signatory to NEPAD agreed to a collaboration between NEPAD Planning and Coordinating Agency (NPCA) and the nongovernmental organizations aimed at boosting agricultural productivity by boldening climate change adaptive capacity at the grassroots level. According to the African Union, the ensuing partnership was to avail technical aid to AU members to enhance CSA implementation. Similarly, the African Development Bank (ADB) together with partners were to support African countries on investing in CSA. Using FAO guidelines, several African countries have identified specific agriculture investment needs for the upscaling of CSA implementation (FAO 2012). More so, they have revised their National Agriculture Investment Plans.

On the analysis of the National Adaptation Plans of Action (NAPA) among the 47 least developed countries, about half (22) of the countries explicitly recognized the needed role from private sector (Pauw and Pegels 2013). According to the study, some of the countries broadly identified areas of engagement for the private sector. The countries view the private sector as a partner in the adaptation of sustainable sources of energy - specifically transition from wood and charcoal into solar and wind, agricultural practices, and water management. However, only one country (Mali) recognized the cofinancing role of the private sector (Pauw and Pegels 2013), showing low levels of awareness of the role of the private sector in climate adaptation. Alternatively, the failure to recognize the private sector in the NPAs may be intentional delusion to facilitate the scaling up of public funding. Altogether, $90 \%$ of the NPA recognized inadequate finance resources as a potential barrier to climate adaptation, and at the same time, only about $10 \%$ presented lack of private sector engagement as a barrier (Pauw and Pegels 2013). 
Reportedly, national organizations have rapidly embraced CSA implementation. However, CSA is at its infancy due to a myriad of problems. Specifically, Barnard et al. (2015) present limited access to credit and finance as a major obstacle towards the adoption of CSA practices as they hinder access to farm tools and inputs. Further, Milder et al. (2011) argue initial investment into CSA is prohibitive especially for small farmers that according to Branca et al. (2012) constitute the largest share of agriculture investment in Africa. Mhlanga et al. (2010) reported that investment in agriculture by banks in Africa is barely $10 \%$ and attracts relatively high-interest rates. However, to unlock such potential, there is a need to carefully detail the barriers that may hold back CSA development in Africa.

Partey et al. (2016) noted that there is a limited understanding of the CSA concept and framework. All across Africa, farming practices and systems differ creating uncertainties into what technologies or activities constitute CSA. As the advocacy for CSA grows, essential stakeholders such as financial institutions fail to recognize their role in influencing the smart agriculture initiative hence failing to promote the scaling up investment. Williams et al. (2015) note that initially, there were policies, strategies, plans, and programs that were formulated without being informed by the concept of CSA. This has resulted in incompatibility challenges and at times leads to policy duplication. As an observation by Williams et al. (2015), the majority of the West African countries are yet to integrate climate change adaptation into their respective country's national agriculture programs. Additionally, there is limited investment in CSA due to a narrow number of technological packages and financial products (Partey et al. 2016). A factor that can be attributed to limited economic documentation of CSA implications that lead to a failed business case to attract investment (Sylla et al. 2012; Giller et al. 2009). Pauw and Pegels (2013) noted that attracting adaptation investment from the private sector may be challenging in developing countries due to constrained business environment, underdeveloped private sectors and lack of experience with adaptation engagement among the private sector. To help in the risk analysis necessary for private investment decision-making, there is need to hypothesize that there are major challenges that hinder private sector investment in climate-smart agriculture in Africa.

\section{Countries Selection}

This section describes the process of determining the country of focus for the assessment of the CSA financial potential as well as the barriers to CSA financing in Sub-Saharan Africa. The work carried out was conducted in 14 countries: 4 from East, West, and Southern Africa and an additional 2 countries from Central Africa. The countries are about $30 \%$ representative of the four different agroecological regions in Africa. Table 1, depicts the number of countries in each region and the number of those shortlisted. 
Table 1 Number of shortlisted countries from each geographical region in Africa

\begin{tabular}{l|l|l|l}
\hline $\begin{array}{l}\text { S. } \\
\text { No. }\end{array}$ & $\begin{array}{l}\text { Sub-Saharan African } \\
\text { region }\end{array}$ & $\begin{array}{l}\text { Total number of } \\
\text { countries }\end{array}$ & $\begin{array}{l}\text { Number of countries shortlisted for } \\
\text { climate finance study }\end{array}$ \\
\hline 1 & Central Africa & 7 & 2 \\
\hline 2 & East Africa & 13 & 4 \\
\hline 3 & Southern Africa & 14 & 4 \\
\hline 4 & West Africa & 15 & 4
\end{tabular}

\section{Sampling Selection Method}

The shortlisted countries were based on five key indicators related to climate change. First, as the study relates to unlocking private capital, the foreign direct investment (FDI) inflows into each country was factored in. Secondly, a consideration was given to the climate risk score to enable the inclusion of the most vulnerable countries in detailed research. Thirdly, desktop research was undertaken to identify the climate finance requirements for each of the countries. Fourthly, it was a consideration of the ease of doing business to provide key insight into government initiatives. Lastly, the GDP and its growth curve were put into consideration to determine the demand for each country. In each indicator, countries were ranked from the highest to the lowest as shown in Table 2.

The data for each indicator was collected from credible sources such as the World Bank and the International Finance Corporation. The data on climate risk score was retrieved from the Global Climate Risk Index score released by Germanwatch. Nationally Determined Contributions that were submitted by each country as per the Paris Agreement were reviewed to determine the climate finance requirement. Data from the Germanwatch that monitors the impacts of weather-related loss events were used to develop the country ranks for climate risk index. Climate Risk Index data for 2017 was used as it was the most recent.

\section{Situational Analysis of Priority Countries}

After the indicator-based ranking, comprehensive desk research was carried out on climate vulnerabilities, climate change scenarios, national priorities, and policies related to climate change adaptation. Subsequently, a review of Nationally Determined Contributions and Sustainable Development Goals (SDGs) of the selected countries was conducted to identify climate adaptation investment potential.

\section{Estimating Climate Investment Potential}

To estimate the investment potential for climate-smart agriculture up to 2030, there was detailed desk research of documents like the National Adaptation Plan Actions, Climate-Smart Agriculture - country factsheets, Economic Cost of Adaptation, 


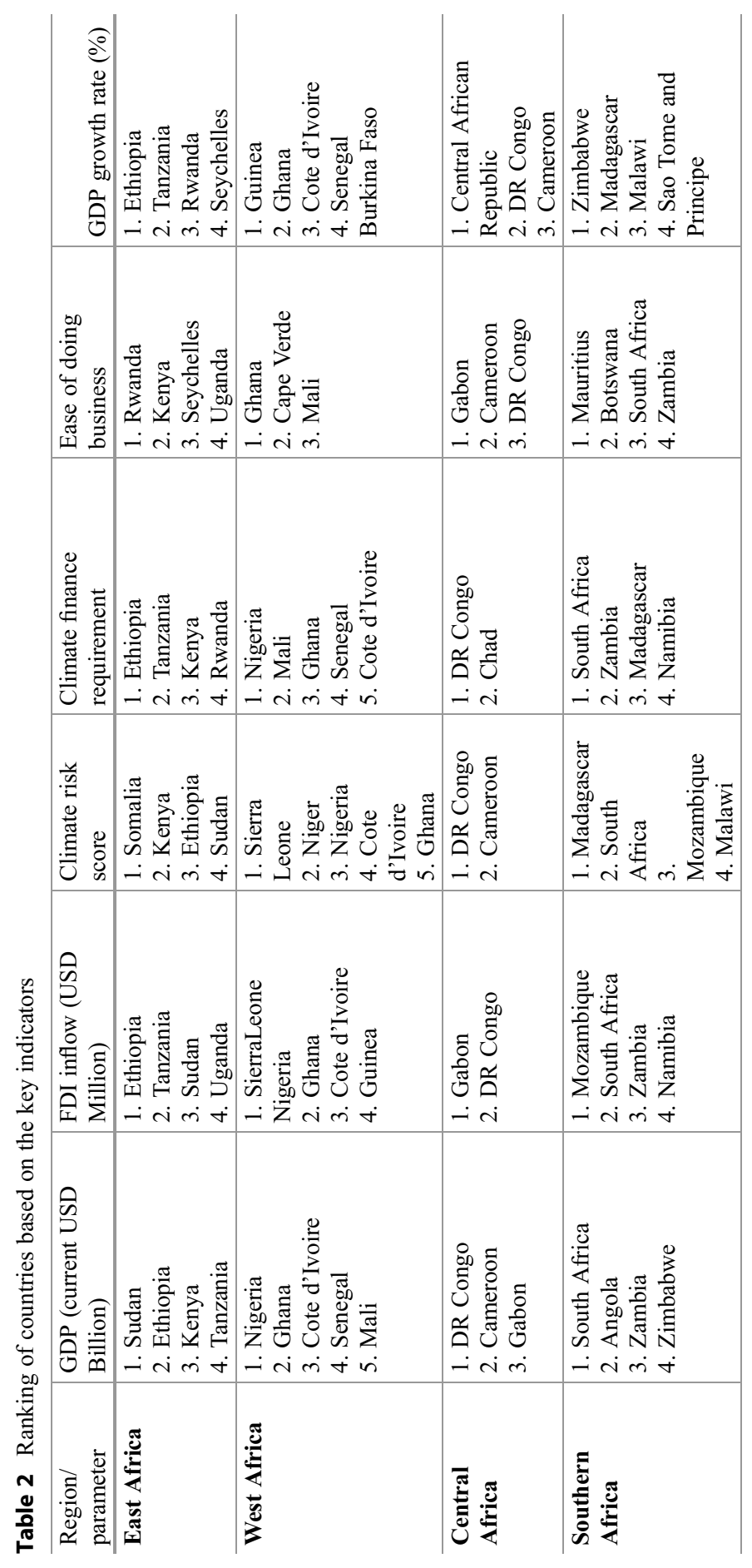


NDCs, and other strategies, plans, and programs on the focus countries. More so, the approach for estimating CSA investment potential was with a consultation with a wide range of stakeholders to assess the status of climate finance sources and programs.

Experts were drawn from relevant government Ministries, stakeholders in the CSA sector, CSA technology providers, think tanks, civil society organizations (CSOs), Climate Bonds Initiative, and organizations like Africa Renewable Energy Initiative and other policy research institutions to take part in semi-structured face to face interviews. Further, national consultative and validation workshops were conducted with private and public sector players such as the UNFCCC, WB, AfDB, IFC, and other donors. To ensure a bottom-up approach, market players early-stage, mid-stage, and matured companies - were consulted in developing priority actions for the implementation of CSA technologies. In every stakeholder consultation, a checklist was developed against which information was collected. The information collected was both qualitative and quantitative. To triangulate and complement the empirical findings, the results were further discussed with limited expert stakeholders to assess their opinions and thoughts.

\section{CSA Financial Potential and Barriers Associated with CSA Financing}

\section{Financing Potential for Climate-Smart Agriculture in Sub-Saharan Africa}

To assess climate smart potential, many adoption studies generally rely on the agricultural practices and opportunities that can be utilized by the private sector (Tesfaye et al. 2017; Pauw and Pegels 2013; Zougmoré et al. 2018; Atteridge and Dzebo 2015; Intellecap 2010; Pauw 2014; Pauw et al. 2015). The evidence generated is qualitative that is rather weak failing to constitute a strong business case to complement the adaptation finance gap in the context of developing countries. It is important to note that the failure to have an argument based on quantitative potential in pursuing private sector engagement in climate-smart agriculture contributes to the adaptation paradox. It is true there are insightful estimates on the business potential of climate-smart agriculture but that is mostly within high level and political contexts. However, agricultural vulnerability is essentially within the local contexts. To engage the local private sector and institutions in implementing the adaptation needs, there is an absolute urgency to create awareness on the underlying climatesmart agriculture potential, investment trends, and agricultural practices with the maximum returns.

Table 3 presents quantified climate investment potential among 14 countries in SSA. It can be observed that Ethiopia has the greatest climate-smart agriculture investment potential of USD 26.4 million. It is followed by Nigeria, Kenya, Madagascar, and Ghana at 17.0, 8.9, 8.4, and 5.5 million USD, respectively. The rest of the countries have a CSA investment potential between the range of 0.3 and 2 million 
Table 3 Climate-smart agriculture investment potential

\begin{tabular}{l|l|l}
\hline S. & & \\
No. & Country & Climate-smart agriculture finance potential (USD millions) \\
\hline 1 & Ethiopia & 26,400 \\
\hline 2 & Nigeria & 17,028 \\
\hline 3 & Kenya & 8,910 \\
\hline 4 & Madagascar & 8,360 \\
\hline 5 & Ghana & 5,510 \\
\hline 6 & Rwanda & 2,200 \\
\hline 8 & Senegal & 2,092 \\
\hline 9 & Cameroon & 1,800 \\
\hline 10 & Mozambique & 1,760 \\
\hline 11 & Ivory Coast & 1,656 \\
\hline 12 & Tanzania & 1,500 \\
\hline 13 & Congo & 1,563 \\
\hline 14 & Zambia & 392 \\
\hline Total & South Africa & NA \\
\hline
\end{tabular}

up to the year 2030. In the views of the stakeholders, the cumulative investment potential of CSA is about $40 \%$. Specifically, the private sector can tap into addressing climate change vulnerabilities that are tied to agriculture and water creating a win-win scenario for both the investors and farmers. The figures in Table 3 support the hypothesis that the CSA investment potential is quantifiable and varies across various countries in Africa. According to Quantum that ranks African countries based on Investment Index based on: economic growth, risk factor, business environment, demographic, social capital, and liquidity factor, South Africa, Kenya, and Ethiopia emerged among the top ten (Quantum Global 2018). Essentially, the private sector can single out these three countries on climate-smart sectors.

Climate financing comes from various sources, multilateral and bilateral, public and private, and possibly alternative sources such as remittances (Bendandi and Pauw 2016). According to the OECD (2018)), public climate finance from developed to developing countries in 2017 was at USD 56.7 billion that was a 17\% increase from the previous year. Public finance can be used to unlock additional climate funding especially from the private sources that would generally increase the domestic revenue base through proportionate increase of agricultural finance. Despite the continued flow of public financing into developing countries to promote climate adaptation, its documentation as climate-smart agricultural potential for private sector exploration remains unclear.

Table 4 shows that the highest CSA investment is evenly spread among the top five highest receivers. Zambia has the highest investment at 29.4 followed by Madagascar with 28.1, Tanzania 23.4, Nigeria 19.8, and Rwanda 17.31. However, it should be noted that the inflow of multilateral funds in form of adaptation fund supply is $75 \%$ grant, $20 \%$ concessional loan, and $5 \%$ equity. Consequently, 
Table 4 Investment trends in climate-smart agriculture in the shortlisted countries

\begin{tabular}{l|l|l}
\hline S. No. & Country & Contributions to climate-smart agriculture per year in USD millions \\
\hline 1. & Zambia & 29.40 \\
\hline 2. & Madagascar & 28.06 \\
\hline 3. & Tanzania & 23.42 \\
\hline 4. & Nigeria & 19.78 \\
\hline 5. & Rwanda & 17.31 \\
\hline 6. & Ethiopia & 17.26 \\
\hline 7. & Mozambique & 15.77 \\
\hline 8. & Senegal & 14.96 \\
\hline 9. & Cote D'Ivore & 13.32 \\
\hline 10. & Cameroon & 9.67 \\
\hline 11. & South Africa & 7.99 \\
\hline 12 & Ghana & 7.06 \\
\hline 13 & Kenya & 5.57 \\
\hline 14 & Congo & 4.26 \\
\hline Total & & $\mathbf{2 1 3 . 8 3}$
\end{tabular}

classifying countries according to those with the highest grant inflows that are leaned to agriculture and water sectors, we have Tanzania, Zambia, Ethiopia, Madagascar, and Mozambique.

On average, there is a $98 \%$ funding gap in climate-smart agriculture. Out of which, 15-20\% can be met by multilateral funds and investments from local governments, financial institutions, and private investors. Arguably, Sub-Saharan Africa will be the global destination for climate financing.

Table 5 identifies some key potential opportunities that could be explored by the private sector across Sub-Saharan Africa. In general, there are investment opportunities in integrated pest and disease control, soil fertility and water management, adoption of new agriculture technologies and practices in addition to farm diversification.

\section{Barriers Hindering the Private Sector from Investing in CSA in Africa}

According to the World Bank (2016) observations, investment alone will not be effective in promoting sustainable agriculture. The investments will be rendered ineffective by other existing barriers that are important to untangle. Neglecting uncertainties and failing to factor in nonfinancial and financial-related barriers while making financial decisions may result in wrong investment models that have detrimental effects on both the investor and farmers. Among the many difficulties experienced in trying to close in the financing gap, there is need to reflect on three of the most common barriers: financial, policy and regulatory, government and institutional barriers. Collectively, these barriers directly or indirectly result to income and liquidity variability mostly among the majority of the agriculture sector players smallholder farmers. 
Table 5 CSA implementation measures with the maximum potential for investment by the private sector

\begin{tabular}{|c|c|c|}
\hline $\begin{array}{l}\text { S. } \\
\text { No. }\end{array}$ & Country & $\begin{array}{l}\text { Climate-smart agriculture interventions with the maximum potential to } \\
\text { attract private investment }\end{array}$ \\
\hline 1 & Ethiopia & $\begin{array}{l}\text { (a) Periodical application of biofertilizers } \\
\text { (b) The precise application of fertilizer }\end{array}$ \\
\hline 2 & Nigeria & (a) Agriculture-based research and development \\
\hline 3 & Kenya & $\begin{array}{l}\text { (a) Legume-based feeds for dairy cows } \\
\text { (b) Organic manure composting and distribution } \\
\text { (c) Crop rotation techniques }\end{array}$ \\
\hline 4 & Madagascar & $\begin{array}{l}\text { (a) Application of multi-hazard early warning systems and pest control } \\
\text { (b) Integrated water resources management specifically in arid areas } \\
\text { (c) Large-scale adoption of resilient agriculture }\end{array}$ \\
\hline 5 & Ghana & $\begin{array}{l}\text { (a) Agronomic-based support in soil and water conservation techniques } \\
\text { (b) Enhancing agricultural productivity } \\
\text { (c) Widespread better use of quality fertilizer among the smallholder } \\
\text { farmers } \\
\text { (d) Promoting agricultural diversification to boost income generation } \\
\text { (e) Foster adoption of agriculture-based technologies in water } \\
\text { management and small-scale irrigation }\end{array}$ \\
\hline 6 & Rwanda & $\begin{array}{l}\text { (a) Soil management in wetlands } \\
\text { (b) Multiple mechanisms in pest and disease control } \\
\text { (c) Adoption of green manure including crop biomass }\end{array}$ \\
\hline 7 & Senegal & $\begin{array}{l}\text { (a) Adoption of sustainable land management technologies } \\
\text { (b) Enhancing the adoption of agriculture insurance policies } \\
\text { (c) The wide reach of climate-based information } \\
\text { (d) Trigger a market base for crop and forest products }\end{array}$ \\
\hline 8 & Cameroon & N/A \\
\hline 9 & Mozambique & $\begin{array}{l}\text { (a) Adoption of drought-resistant crop varieties } \\
\text { (b) Use of integrated pest control and organic manure } \\
\text { (c) Management of crop-based biomass } \\
\text { (d) Sustainable water management } \\
\text { (e) Diversification of sources of livelihoods }\end{array}$ \\
\hline 10 & Cote D'Ivore & $\begin{array}{l}\text { (a) Improvement in agricultural production technologies } \\
\text { (b) Introduction of agricultural produce storage facilities } \\
\text { (c) Popularizing climate-resilient crop varieties }\end{array}$ \\
\hline 11 & Tanzania & $\begin{array}{l}\text { (a) Management of soil fertility and extension of agriculture services } \\
\text { (b) Introduction of in situ water harvesting techniques and agriculture- } \\
\text { based insurance policies } \\
\text { (c) Adoption of high yields drought-resistant seed varieties and crop } \\
\text { diversification } \\
\text { (d) Use of inter alia CSA and widespread knowledge }\end{array}$ \\
\hline 12 & Congo & N/A \\
\hline 13 & Zambia & $\begin{array}{l}\text { (a) Widespread adoption of drought-resistant crops and agroforestry. } \\
\text { (b) Increased biomass capacity. } \\
\text { (c) Encouraging fire management and adoption of integrated pest and } \\
\text { disease control. }\end{array}$ \\
\hline 14 & South Africa & $\begin{array}{l}\text { (a) Adoption of conservation agriculture and better cropping practices. } \\
\text { (b) Diversification of farm activities. } \\
\text { (c) Livestock and pasture management }\end{array}$ \\
\hline
\end{tabular}


Evidence by Africa Climate Week shows that over $65 \%$ of African countries have started their implementation of the Nationally Determined Contributions (Africa Climate Week 2019). Moreover, $80 \%$ of the surveyed firms have attained substantial mileage in the adoption and implementation of climate change adaptation measures. However, the survey also established that more than half of African countries face problems in mobilizing both national and international funds. Further on, the Africa Climate Week study found out that over $75 \%$ of the surveyed countries did not have an efficient financing strategy with an additional 67\% lacking agriculture-based financial instruments. Conclusively, despite the investment potential associated with CSA in Sub-Saharan Africa, it is worthwhile to note that access to climate finance at scale presents a major setback. Divulging more information on financial factors that have large uncertainty along with other intertwining obstacles will be of high value for enhancing investment decisions and policy advocacy. Some of the challenges facing the continent when it comes to CSA financing includes:

(i) Overlapping policies on climate change that are weakly enforced.

(ii) Inadequate and unstructured provision for climate funding in the respective country's national budgets.

(iii) Insufficiency in terms of government capacity to satisfy the required standards and procedures needed in developing viable projects and bureaucratic funding processes.

(iv) Inadequate knowledge and awareness on the sources of climate finances among the stakeholders in addition to constrained private sector engagement.

(v) Lack of appreciation that climate change is both a developmental and environmental concern leading to a silo approach that impairs financing and problemsolving.

Looking more closely at the CSA barriers, most of the stakeholders agreed that financial-related barriers were the greatest hindrance towards unlocking the potential in climate-smart agriculture by the private sector. Secondly, about $80 \%$ of the stakeholders interviewed expressed that policy and regulatory setbacks were holding back the private sector from being involved in undertaking climate change interventions in Africa. Additionally, stakeholders highlighted that economic-, infrastructure-, and institutional-related constraints prevented the private sector interest in CSA. It was important to disaggregate the various financial, regulatory, and governance barriers.

Financing products and instruments for climate-smart projects financing from the local commercial banks do not only have high-interest rates and collateral pledges but also short lending tenures. Lending interest rates for the local banks across Africa is between $18 \%$ and $20 \%$ and in most cases require $100 \%$ collateral for one to acquire an agricultural loan. The local commercial banks view climate-smart projects as highly risky due to their limited experience in the newly emerged sector. Arguably, the inadequate data on risk-profile data for climate-smart projects contribute to the financier's views. Also, the target short-term payback period of between 1 and 3 years set for climate-smart projects does not fit with the loan tenors. 
Unlike countries such as Bangladesh that experienced a large uptake of climatesmart approaches due to a huge number of microfinance institutions, in SSA, the microlending infrastructure is poorly developed. Microfinancing in the majority of the African countries is still at its infancy, and product sales targeting climate-smart agriculture is virtually nonexistent.

There are conspicuously limited national funds that have been mobilized and distributed at low costs to the private sector. National funds aimed at financing climate-smart agriculture could be of great help in invoking private sector participation with the high costs attracted by commercial bank alternations. However, in the majority of the African countries, national funds for smart agriculture are inactive or are lacking.

Under the current situation, CSA financing in Sub-Saharan African is based on donor funding which is mostly prohibitive due to high mainstreaming and upscaling costs. The import and export of capital in SSA countries are both bureaucraticlengthy and costly. Climate-smart entrepreneurs and start-ups that are the engine behind innovation and efficient use of resources lack capital. Much of the funding into early-stage business models and start-ups is through private equity, venture capital, or angel investor community that lack the pool of resources necessary to satisfy all sectors. Innovators end up competing against each other dwindling each other's chances of survival. Measures such as promoting blended finance, introducing guarantee funds, encouraging fiscal incentives, establishing accessible local climate funds, and developing friendly investment policies will be key in overcoming the financial barriers and stimulating investor interest.

Key players in smart agriculture need policies that recognize and support the implementation of CSA practices. Investor-based services in smart agriculture like risk insurance and safety nets need considerable policy support. However, in the majority of the SSA countries, several CSA policy loopholes impair the actualization of the action plans. There is a problem with CSA coordination and mainstreaming into the general public. Therefore, the expenditure and planning systems are blurred both at the local, national, and regional levels. It will be critical to strengthening existing synergies to enhance food security programs. The absence of effective policies and regulations discourages lending and creates obstacles to the flow of cash to agriculture. For instance, lack of appreciation by the government of the agriculture economic and market potential lead to ignored subsidies that discourage the development of private sector-based solutions into enhancing climate adaptation.

Financial institutions have limited knowledge on climate-smart projects thereby hindering their investment interest. Both banks and microfinance lack the understanding of the operations of agriculture smart and continuously demonstrate an experience deficit. In such instances, the financial institutions need training on agriculture smart technologies to tailor-make suitable business models and financing options. Circulation of information will be necessary to get rid of the high-risk perception by the lending institutions. Key stakeholders, among them government ministries, nongovernmental organizations, and farmers cooperatives have a knowledge gap on CSA limiting its uptake. It is important for the government to be aware of the agriculture potential in order to promote the development of other sectors that 
are not necessarily related to agriculture but are indirectly vital for its development, such as the infrastructure and communication networks.

\section{Conclusion}

Modern day agriculture has to meet increased food demand due to burgeoning population and evolving diets amidst dwindling crop yield, diminishing natural resources, and constrained biodiversity. Worse is that the continuously warming climate is greatly undermining agricultural productivity with disastrous effects on land, crops, and farmers. Fortunately, adoption of climate-smart agriculture can be a significant part of solving the environmental crisis of climate change. Through sustainable agriculture, there is the capacity to increase agricultural productivity hence increasing incomes through built and adaptive farming resilience. However, this is not possible without substantial increase in the amount of climate-smart investment that will increase the access to finance. There exist huge financial gaps in CSA investment due to the perceptions of high risks and low profitability. Robust financial investment from the private sector can greatly accelerate the adoption of climate-smart agriculture leading to societal gains of poverty reduction by supporting the global food system. Through quantifiable evidence, this chapter has practically provided a translation of the investment potential into investor "language" with the sole objective of invoking private sector interest. The work carried out as the basis of this chapter has gone a step further to identify the maximum potential areas within the smart agriculture in respective countries with a conclusion of disaggregating the sector barriers.

Sub-Saharan Africa has a substantial climate finance investment potential for the private sector. Countries need to promote low carbon development, resource use efficiency, and resilience building in their development strategies and policies. International collaborations should seek to promote regional capacity building in accessing climate finance to promote sustainable development. Multilateral and national climate financing mechanisms should be based on a country's commitment to climate change adaptation. There is a need to strengthen the regulatory environment by creating effective policies and subsidizing the private sector investment to spur adaptation action. SSA needs to foster regional and cross-border collaborations to enhance an integrated approach towards climate change-related issues. National governments need to harness the innovative capacity by raising capital for the private sector that is driving climate investments. Channels to facilitate climate finance into cities and urban areas where there is access to a greater number of people is necessary to greatly reduce the poverty levels.

The contribution of this work is on the conceptual clarifications of the CSA investment potential for the private sector. However, it fails to distinguish the opportunities as either for the domestic or/and international private sector. Again, the chapter outlines climate-smart agriculture potential at a national level. To greatly elicit the private sector, there is need to further breakdown the potential into local contexts. More so, future research can explore the financial potential of each of the 
identified agricultural practices either regionally or nationally. Further, to objectively attract private investment into climate financing in developing countries, there is need to clearly define the short- and long-term investment activities that can be key for the financial institutions decision-making. The identified limitations create inadequacies in precisely defining the role of the private sector in their increasing engagement on climate finance.

National governments in Sub-Saharan Africa are supporting low carbon and climate-resilient development through local budget allocations, commitments to international programs and strategies that alone cannot achieve the sustainable development goals. They can further enhance their adaptation action through partnering with the private sector to alleviate the funding gap as a result of broadening public debt crises and increasing climate finance needs. This is by creating an enabling environment both in terms of policy, regulations, and infrastructure.

\section{References}

Africa Climate Week (2019) Africa climate week ends with calls for investments to tackle climate change - United Nations Sustainable Development. Retrieved from https://www.un.org/sustaina bledevelopment/blog/2019/04/africa-climate-week-ends-with-calls-for-investments-to-tackleclimate-change/

Atteridge A, Dzebo A (2015) When does private finance count as climate finance? Accounting for private contributions towards international pledges. SEI discussion brief. Stockholm

Barkhordarian A, Von Storch H, Bhend J (2012) The expectation of future precipitation change over the Mediterranean region is different from what we observe. Clim Dyn 40(1-2):225-244. https://doi.org/10.1007/s00382-012-1497-7

Barnard J, Manyire H, Tambi E, Bangali S (2015) Barriers to scaling up/out climate smart agriculture and strategies to enhance adoption in Africa. Retrieved from Forum for Agricultural Research in Africa, Accra, Ghana website https://www.nepad.org/publication/barriers-scalingupout-climate-smart-agriculture-and-strategies-enhance-adoption

Bendandi B, Pauw P (2016) Remittances for adaptation: an 'alternative source' of international climate finance? In: Migration, risk management and climate change: evidence and policy responses, pp 195-211. https://doi.org/10.1007/978-3-319-42922-9_10

Branca G, Tennigkeit T, Mann W, Lipper L (2012) Identifying opportunities for climate-smart agriculture investments in Africa. FAO

Buah SS, Ibrahim H, Derigubah M, Kuzie M, Segtaa JV, Bayala J et al (2017) Tillage and fertilizer effect on maize and soybean yields in the Guinea savanna zone of Ghana. Agric Food Secur 6 (1). https://doi.org/10.1186/s40066-017-0094-8

Christiansen L, Ray AD, Smith JB, Haites E (2012) Accessing international funding for climate change adaptation. Climate and sustainable development. UNEP Risø Centre on Energy, Roskilde

ECOWAS is in High Level Forum of Climate Smart Agriculture Stakeholders Intervention Framework for the Development of Climate Smart Agriculture under the West Agricultural Policy (ECOWAP/CAADP) implementation With technical facilitation by: In partnership with: Accelerating the implementation of ECOWAP/CAADP High Level Forum of Climate Smart Agriculture Stakeholders in West Africa Bamako (Mali), June 15-18, 2015 Intervention Framework for the Development of Climate Smart Agriculture under the West Africa Regional Agricultural Policy (ECOWAP/CAADP) implementation Process

Elrafy M (2009) Impact of climate change: vulnerability and adaptation of coastal areas. Report of the Arab Forum for Environment and Development 
FAO (2012) Identifying opportunities for climate-smart agriculture investments in Africa. Retrieved from http://www.fao.org/docrep/015/an112e/an112e00.pdf

FAO (2013) Climate smart agriculture source book. Retrieved from Food and Agriculture Organization of the United Nations website http://www.fao.org/3/i3325e/i3325e.pdf

FAO, IFAD and WFP (2014) The State of Food Insecurity in the World 2014. Strengthening the enabling environment for food security and nutrition. Rome, FAO.

Giller KE, Witter E, Corbeels M, Tittonell P (2009) Conservation agriculture and smallholder farming in Africa: the heretics' view. Field Crop Res 114(1):23-34. https://doi.org/10.1016/j. fcr.2009.06.017

Hoerling M, Hurrell J, Eischeid J, Phillips A (2006) Detection and attribution of twentieth-century northern and southern African rainfall change. J Clim 19(16):3989-4008. https://doi.org/ $10.1175 /$ jcli3842.1

Intellecap (2010) Opportunities for private sector engagement in urban climate change resilience building. Author, Hyderabad

IPCC (2014) Climate change 2014: impacts, adaptation and vulnerability. IPCCWGIIAR5 technical summary. Retrieved from http://ipccwg2.gov/AR5/images/uploads/WGIIAR5-TS_FGDall.pdf

Jalloh A, Roy-Macauley H, Sereme P (2012) Major agro-ecosystems of West and Central Africa: brief description, species richness, management, environmental limitations and concerns. Agric Ecosyst Environ 157:5-16. https://doi.org/10.1016/j.agee.2011.11.019

Lobell DB, Bänziger M, Magorokosho C, Vivek B (2011) Nonlinear heat effects on African maize as evidenced by historical yield trials. Nat Clim Chang 1(1):42-45. https://doi.org/10.1038/ nclimate 1043

Maguza-Tembo F, Edriss A, Mangisoni J (2017) Determinants of climate smart agriculture technology adoption in the drought prone districts of Malawi using a multivariate probit analysis. Asian J Agric Ext Econ Soc 16(3):1-12. https://doi.org/10.9734/ajaees/2017/32489

Mapfumo P, Onyango M, Honkponou SK, El Mzouri EH, Githeko A, Rabeharisoa L et al (2015) Pathways to transformational change in the face of climate impacts: an analytical framework. Clim Dev 9(5):439-451. https://doi.org/10.1080/17565529.2015.1040365

Mbow C, Smith P, Skole D, Duguma L, Bustamante M (2014) Achieving mitigation and adaptation to climate change through sustainable agroforestry practices in Africa. Curr Opin Environ Sustain 6:8-14. https://doi.org/10.1016/j.cosust.2013.09.002

Mhlanga N, Blalock G, Christy R (2010) Understanding foreign direct investment in the southern African development community: an analysis based on project-level data. Agric Econ 41(34):337-347

Milder J, Majanen T, Scherr S (2011) Performance and potential of conservation agriculture for climate change adaptation and mitigation in Sub-Saharan Africa: an assessment of WWF and CARE projects in support of the WWF-CARE alliance's rural futures initiative. Retrieved from https//:Barriers-to-scaling-up-out-CSA-in-Africa.pdf

Nciizah AD, Wakindiki II (2015) Climate smart agriculture: achievements and prospects in Africa. J Geosci Environ Protection 03(06):99-105. https://doi.org/10.4236/gep.2015.36016

OECD (2018) Public climate finance to developing countries is rising - OECD. Retrieved from $\mathrm{https}$ ://www.oecd.org/environment/public-climate-finance-to-developing-countries-is-rising.htm

Partey ST, Thevathasan NV, Zougmoré RB, Preziosi RF (2016) Improving maize production through nitrogen supply from ten rarely-used organic resources in Ghana. Agrofor Syst. https://doi.org/10.1007/s10457-016-0035-8

Pauw WP (2014) Not a panacea: private-sector engagement in adaptation and adaptation finance in developing countries. Clim Pol 15(5):583-603. https://doi.org/10.1080/14693062.2014.953906

Pauw P, Pegels A (2013) Private sector engagement in climate change adaptation in least developed countries: an exploration. Clim Dev 5(4):257-267. https://doi.org/10.1080/17565529.2013.826130

Pauw WP, Klein RJ, Vellinga P, Biermann F (2015) Private finance for adaptation: do private realities meet public ambitions? Clim Chang 134(4):489-503. https://doi.org/10.1007/s10584-015-1539-3

Quantum Global (2018) Africa investment index 2018. Retrieved from Renew website https://quantumglo balgroup.com/wp-content/uploads/2017/04/Africa_Investment_Index_April_2017_18.04.2017Final_ Curves.pdf 
Radhouane L (2013) Climate change impacts on North African countries and on some Tunisian economic sectors. J Agric Environ Int Dev 107:101-113

Sanou J, Bationo BA, Barry S, Nabie LD, Bayala J, Zougmore R (2016) Combining soil fertilization, cropping systems and improved varieties to minimize climate risks on farming productivity in northern region of Burkina Faso. Agric Food Secur 5(1). https://doi.org/10.1186/s40066-016$0067-3$

SER (2011) Advies Ontwikkeling door duurzaam ondernemen. Sociaal Economische Raad, Den Haag

Surminski S (2013) Private-sector adaptation to climate risk. Nat Clim Chang 3(11):943-945. https://doi.org/10.1038/nclimate2040

Sylla MB, Gaye AT, Jenkins GS (2012) On the fine-scale topography regulating changes in atmospheric hydrological cycle and extreme rainfall over West Africa in a regional climate model projections. Int J Geophys 2012:1-15. https://doi.org/10.1155/2012/981649

Teklewold H, Mekonnen A, Kohlin G, Di Falco S (2017) Does adoption of multiple climate-smart practices improve farmers' climate resilience? Empirical evidence from the Nile basin of Ethiopia. Clim Change Econ 08(01):1750001. https://doi.org/10.1142/s2010007817500014

Tesfaye K, Kassie M, Cairns JE, Michael M, Stirling C, Abate T et al (2017) Potential for scaling up climate smart agricultural practices: examples from sub-Saharan Africa. Clim Change Manage:185-203. https://doi.org/10.1007/978-3-319-49520-0_12

Thornton PK, Jones PG, Owiyo T, Kruska RL, Herrero M, Orindi V, Bhadwal S, Kristjanson P, Notenbaert A, Bekele N, Omolo A (2008) Climate change and poverty in Africa: Mapping hotspots of vulnerability. Afr J Agr Res Econ 311-2016-5524, 21. https://doi.org/10.22004/ag. econ.56966

Torquebiau E (2015) Whither landscapes? Compiling requirements of the landscape approach. In: Minang $\mathrm{P}$ et al (eds) Climate-smart landscapes. ICRAF, Nairobi

Tran NL, Rañola RF, Ole Sander B, Reiner W, Nguyen DT, Nong NK (2019) Determinants of adoption of climate-smart agriculture technologies in rice production in Vietnam. Int J Clim Change Strategies Manag 12(2):238-256. https://doi.org/10.1108/ijccsm-01-2019-0003

UFCC (2007) Investment and financial flows UNFCCC to address climate change: an update Bonn. Technical Paper FCCC/ TP/2008/7

UFCC (2011) Report of the conference of the parties on its sixteenth session, held in Cancun from 29 November to 10 December 2010

UNDESA (2014) Urbanization prospects. The 2014 revision. Highlights. United Nations, New York

UNEP FI (2009) The materiality of climate change. How finance copes with the ticking clock. United Nations Environment Programme Finance Initiative, Geneva

United Nations, Department of Economic and Social Affairs, Population Division (2019) World urbanization prospects: The 2018 revision (ST/ESA/SER.A/420). United Nations, New York

Wambugu C, Place F, Franzel S (2011) Research, development and scaling-up the adoption of fodder shrub innovations in East Africa. Int J Agr Sustain 9(1):100-109. https://doi.org/ 10.3763/ijas.2010.0562

Williams T, Mul M, Cofie O, Kinyangi J, Zougmoré R, Wamukoya G (2015) Climate smart agriculture in the African context background paper feeding Africa conference, 21-23 Oct 2015

World Bank (2015) World development indicators 2015. Author, Washington, DC

World Bank (2016) Making climate finance work in agriculture. Retrieved from http://documents. worldbank.org/curated/en/986961467721999165/pdf/ACS19080-REVISED-OUO-9-MakingClimate-Finance-Work-in-Agriculture-Final-Version.pdf

Zougmoré R, Traoré AS, Mbodj Y (eds.) (2015) Overview of the scientific, political and financial landscape of climate-smart agriculture in West Africa. Working Paper No. 118. CGIAR research program on climate change, agriculture and food security. Retrieved from http://www.ccafs. cgiar.org

Zougmoré RB, Partey ST, Ouédraogo M, Torquebiau E, Campbell BM (2018) Facing climate variability in sub-Saharan Africa: analysis of climate-smart agriculture opportunities to manage climate-related risks. Cahiers Agric 27(3):34001. https://doi.org/10.1051/cagri/2018019 
Open Access This chapter is licensed under the terms of the Creative Commons Attribution 4.0 International License (http://creativecommons.org/licenses/by/4.0/), which permits use, sharing, adaptation, distribution and reproduction in any medium or format, as long as you give appropriate credit to the original author(s) and the source, provide a link to the Creative Commons license and indicate if changes were made.

The images or other third party material in this chapter are included in the chapter's Creative Commons license, unless indicated otherwise in a credit line to the material. If material is not included in the chapter's Creative Commons license and your intended use is not permitted by statutory regulation or exceeds the permitted use, you will need to obtain permission directly from the copyright holder.

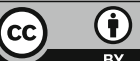

